\title{
POLYMORPHIC LOCI ANALYSIS OF 16S RIBOSOMAL RNA GENE OF BOMBAY DUCK (HARPADON NEHEREUS)
}

Sristy Saha, Zannatul Ferdous, Hawa Jahan, Ashfaqul Muid Khandaker, Reza Md. Shahjahan and Rowshan Ara Begum*

Genetics and Molecular Biology Laboratory, Department of Zoology, University of Dhaka, Dhaka-1000, Bangladesh

\begin{abstract}
Attempts were made to combine morphological and molecular techniques for identification and analysis of evolutionary relationship of commercially important marine lizardfish (Bombay duck) from the Bay of Bengal. For molecular identification, mitochondrial DNA (mtDNA) was extracted using CTAB extraction protocol and 16S rRNA gene was amplified by PCR method. Morphological identification was supported by molecular data generated by $99 \%$ identity of BLAST search result of Harpadon nehereus. The nucleotide sequence of $H$. nehereus was $586 \mathrm{bp}$ long and the $\mathrm{G}+\mathrm{C}$ content was $51 \%$ and intraspecies polymorphic sites were $0.5 \%$. According to interspecies polymorphic sites analysis, $4.9 \%$ polymorphism was observed when $H$. nehereus and $H$. microchir were compared. Phylogenetic tree was constructed and both the Harpadon spp. formed a monophyletic clade. This analysis will be used to study molecular diversity as well as conservation of this fish species.
\end{abstract}

Key words: 16S rRNA gene, Polymorphic loci, mt-DNA, Harpadon nehereus

\section{INTRODUCTION}

Harpadon nehereus, commonly known as the Bombay duck, is a lizardfish, belongs to the family Synodontidae (Whitehead 1984). It lives in the tropical waters of the Indo-Pacific and traditionally caught in the waters of the Bay of Bengal. In Bangladesh, the species is found mainly in the estuaries and also ascends tidal rivers (Rahman 1989, Rahman 2005, Gopal and Chauhan 2006). About, $100 \mathrm{~g}$ flesh of this fish contains 0.85\% carbohydrate, $14.61 \%$ protein, $2.75 \%$ fat, $1.03 \%$ ash and $80.75 \%$ moisture and calcium $339.15 \mathrm{mg}$ (Bhuiyan 1992, Zafar et al. 1993). Dried Bombay duck has commercially importance in the South and Southeast Asia (Rahman 2005).

The elevated market demand and over exploitation of Bombay duck fish may deplete the wild stocks to an unsustainable level (Sarker et al. 2017). Nowadays, the best way to protect a species is not only to preserve its ecosystem but also preserve its genetic resources and diversity (Hedrick 2001). To do so first needs to identify the species. Species identification by using conventional keys only

*Author for correspondence: <rowshanbegumdu@yahoo.com>

(c) 2018 Zoological Society of Bangladesh DOI: https://doi.org/10.3329/bjz.v47i1.42020 
is not enough. Molecular techniques should also be implemented for correct identification. In that case, mitochondrial DNA (mtDNA) plays an important role to species identification and evolutionary relation study. Among mtDNA genes $16 \mathrm{~S}$ ribosomal RNA (16S rRNA) gene is a special region of mitochondrial genome, it has been considered as one of the most informative regions used in phylogenetic studies (Bej et al. 2012, Patwardhan et al. 2004). It is a component of the $30 \mathrm{~S}$ small subunit of prokaryotic ribosome and is $1.5 \mathrm{~kb}$ in length (Devereux and Wilkinson 2004). 16S rRNA gene variation between species and within species is stable (Yang et al. 2014). Although it was originally used to identify an organism, 16S rRNA sequencing was subsequently found to be capable of reclassifying the organism into completely new species, or even genera (Weisburg et al. 1991). 16S rRNA gene along with other mitochondrial genes are used to ensure quality checks on canned fishes and meat and investigate the status of cancerous disease, toxicological status of fish (Sultana 2015). These mitochondrial genes are also used for the purposes of environmental study. 16S rRNA gene sequence is also used in the bar coding of certain vertebrates, for examples amphibian, fishes etc. (Vences et al. 2005).

To investigate the genetic characteristics of $H$. nehereus in this study a partial sequence of the 16S rRNA gene of $H$. nehereus were determined. The sequence was aligned with other sequence of lizardfish to study the number of polymorphic sites and the phylogenetic relationships.

\section{MATERIAL AND METHODS}

The Bombay duck or locally known as loitta (Harpadon nehereus) was collected from Cox's Bazar (Fishery Ghats, fish markets). The fresh specimen was brought to the laboratory of Genetics and Molecular Biology, Department of Zoology, University of Dhaka for further experiment. The sample was then morphologically identified by conventional method. The measurement of different body part of collected fish is shown in Fig. 1. The sample was stored in refrigerator, minimum at $4^{\circ} \mathrm{C}$.

DNA extraction, PCR amplification and sequencing: Genomic DNA was extracted from $0.05 \mathrm{gm}$ muscle tissue of the observed fish species following a method (Doyle and Doyle 1990) with modification. $100 \mu \mathrm{l}$ CTAB extraction buffer and $10 \mu \mathrm{l}$ of proteinase $\mathrm{k}$ were added. The mixture was incubated at $56^{\circ} \mathrm{C}$ overnight. After digestion equal volume of phenol chloroform was added with the supernatant and centrifuged at 13,000 rpm for $5 \mathrm{~min}$. DNA was precipitated with ethanol and dissolved in distilled water. Standard PCR was performed using universal primers and were analyzed by electrophoresis in a $1.5 \%$ agarose 
gel (Faucher et al. 2016). Then, PCR amplification was purified using a purification Kit and sequenced using direct sequencing method.

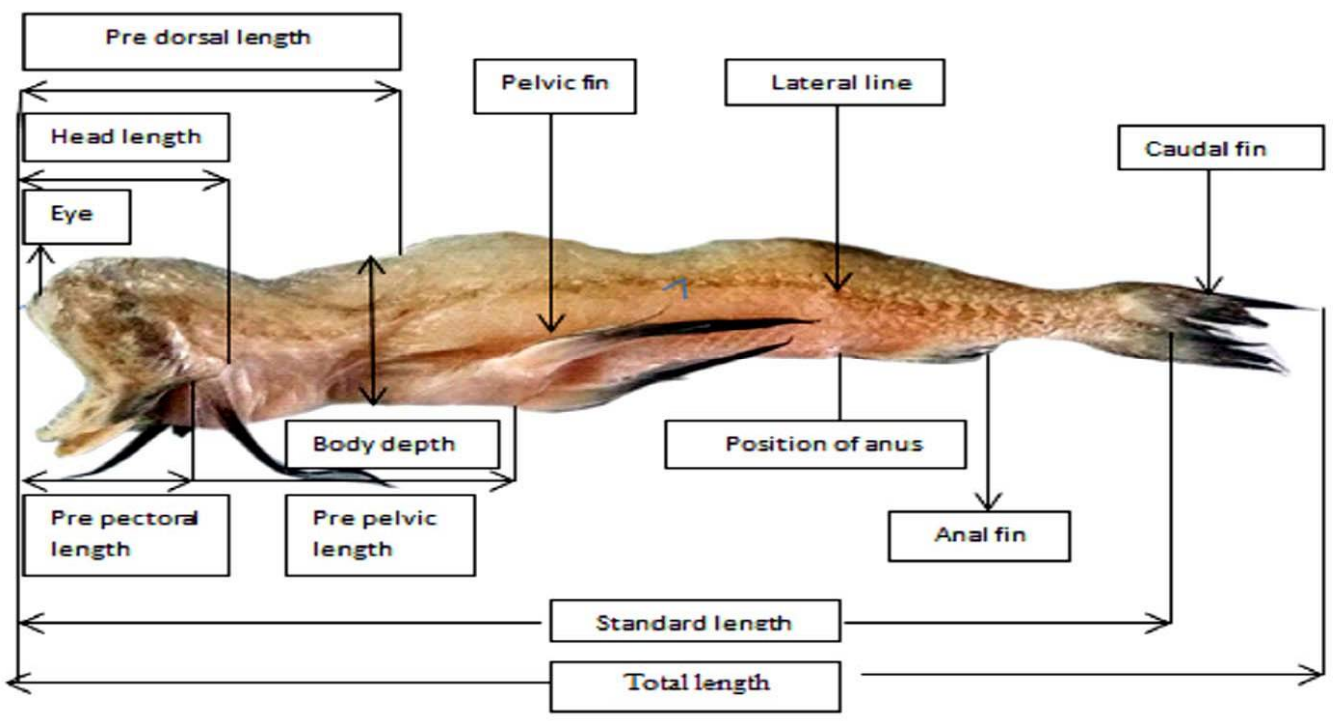

Fig. 1. Measurement of different part of Bombay duck fish.

Bioinformatics analysis: 16S rRNA gene sequence of experimental fish species and other existing sequence of lizard fish were collected from GenBank database (NCBI). Local alignment was done with the help of serial cloner software. MEGA 7 software was used for multiple sequence alignment which was followed by polymorphic sites analysis and for construction of phylogenetic tree. Sequence alignment and pairwise distance calculation is used to conduct two or more biological sequences of similar length.

\section{RESULTS AND DISCUSSION}

After analyses the morphology of Harpadon nehereus, it was observed that body shape lateral elongated, dorsal head profile clearly convex, eyes more or less normal, mouth/snout more or less normal, position of mouth terminal, scales restricted to posterior half of the body, posterior tip of pectoral fin reaching origin of pelvic. Meristic analysis of different body part of the observed fish species are shown in Table 1.

After analyzing the morphological characteristics, the fin formula for the current supplement fish species was found D 12, Pc 11; Pe 9, A 15. Similar type of fin formula finding had been shown in previously conducted research by Whitehead 1984. 
Table 1. Meristic analysis of different body parts (parameters) of observed fish species

\begin{tabular}{llllll}
\hline $\begin{array}{l}\text { Body } \\
\text { measurement }(\mathrm{cm})\end{array}$ & \multicolumn{2}{c}{$\begin{array}{c}\text { Number of spines } \\
\text { and soft rays }\end{array}$} & \multicolumn{2}{c}{$\begin{array}{c}\text { Fin base } \\
\text { length }\end{array}$} \\
\hline TL & 31 & DFN & 1 & DFB & 0.37 \\
SL & 28 & DFS & 0 & PcFB & 0.4 \\
BD & 0.9 & DFSR & 12 & PeFB & 0.8 \\
PDL & 11 & PcFN & 1 & AFB & 0.6 \\
HL & 8.0 & PcFS & 0 & & \\
ED & 0.3 & PeFN & 1 & & \\
PrOL & 0.6 & PeFSR & 9 & & \\
PoOL & 4.6 & AFN & 1 & & \\
IOL & 0.5 & AFS & 0 & & \\
& & AFSR & 15 & & \\
\hline
\end{tabular}

$\mathrm{TL}=$ Total length, $\mathrm{SL}=$ Standard length, $\mathrm{BD}=$ Body depth, $\mathrm{PDL}=$ Pre dorsal length, $\mathrm{HL}=$ Head length, $\mathrm{ED}=$ Eye diameter, $\mathrm{PrOL}=$ Pre orbital length, $\mathrm{PoOL}=$ Post orbital length, $\mathrm{IOL}=$ Inter orbital length, DFN $=$ Dorsal fin number, DFS $=$ Dorsal fin spine, DFSR $=$ Dorsal fin soft ray, PcFN = Pectoral fin number, PcFS $=$ Pectoral fin spine, PcFSR $=$ Pectoral fin soft ray, PeFN = Pelvic fin number, PeFSR $=$ Pelvic fin soft ray, $\mathrm{AFN}=$ Anal fin number, AFS $=$ Anal fin number, AFSR $=$ Anal fin soft ray, $\mathrm{DFB}=$ Dorsal fin base, $\mathrm{PcFB}=$ Pectoral fin base, $\mathrm{PeFB}=$ Pelvic fin base, $\mathrm{AFB}=$ Anal fin base.

DNA extraction and observed banding pattern of isolated DNA: DNA extraction of the samples used in the present study was performed successfully. Agarose gel electrophoresis of extracted genomic DNA was done for being confirmed of successful DNA extraction. Band of the extracted genomic DNA was visualized under the ultraviolet transilluminator was clear and concise as shown in Fig. 2.

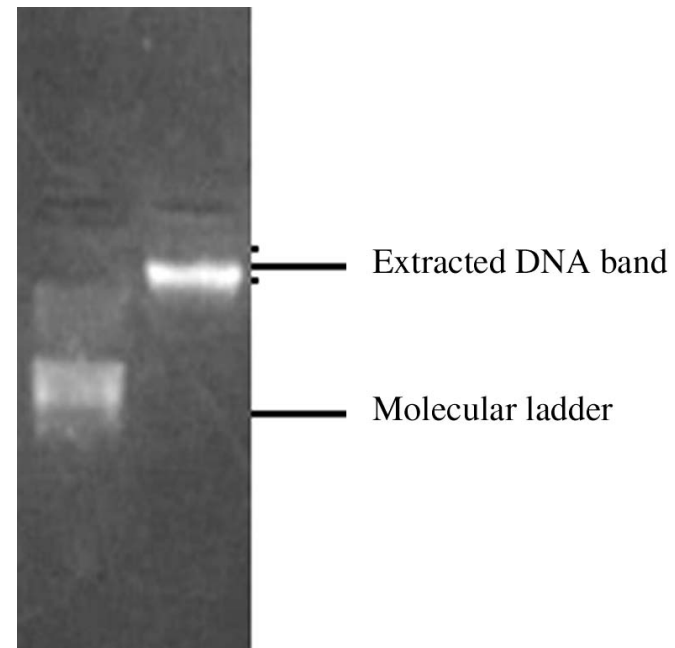

Fig. 2. Extracted genomic DNA band of sample from the collected specimen $H$. nehereus showing in $1.0 \%$ agarose gel. 
Amplification of 16S rRNA gene by polymerase chain reaction: Extracted genomic DNA from observed species was prepared for polymerase chain reaction. The amplified PCR product was then observed by running them through agarose gel of concentration 1.5\% (Fig. 3). Compared with DNA marker, it was revealed that the amplified gene was around 600 base pair long.

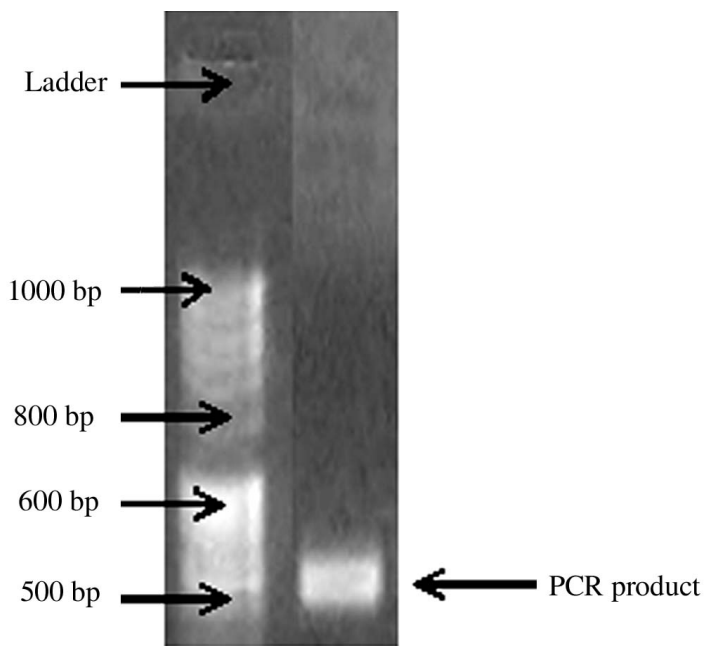

Fig. 3. Amplified DNA band of $16 \mathrm{~S}$ rRNA gene of $H$. nehereus showing in $1.5 \%$ agarose gel.

Nucleotide sequences of 16S rRNA gene: Nucleotide sequence was obtained by direct sequencing method and 586 bp of nucleotide sequence was determined. The obtained sequence is submitted to the GenBank and the accession number is (MK641100). Nitrogen base was analyzed by percentages are shown in Table 2.

Table 2. Percentages of nucleotide base pair of observed fish species $H$. nehereus

\begin{tabular}{lc}
\hline Nucleotide base name & Percentage \\
\hline Adenine (A) & 27.8 \\
Cytosine (C) & 27.0 \\
Guanine (G) & 23.2 \\
Thymine (T) & 21.5 \\
G-C content & 51 \\
A-T content & 49 \\
AT/GC ratio & 0.9 \\
\hline
\end{tabular}

According to this analysis, the region amplified was GC rich, whereas the whole 16S rRNA gene shows AT richness, compared to GC (Bo et al. 2013). 
Intraspecific variation of 16S rRNA gene: For further analysis multiple sequence alignment was done to investigate the intraspecific comparison between $H$. nehereus from Bangladesh used in the present study and China (JX534239). The alignment of 16S rRNA gene of $H$. nehereus from two different region indicated nucleotide polymorphism varies at 3 positions with $0.5 \%$ polymorphism and location are shown in Table 3.

Table 3. Polymorphic sites analysis of 16S rRNA gene of Harpadon nehereus from Bangladesh and China

\begin{tabular}{cccc}
\hline Serial No. & Polymorphic sites & $\mathrm{BH}$ & $\mathrm{CH}$ \\
\hline 1 & 204 & $\mathrm{~T}$ & $\mathrm{~A}$ \\
2 & 242 & $\mathrm{C}$ & $\mathrm{T}$ \\
3 & 357 & $\mathrm{~T}$ & $\mathrm{C}$ \\
\hline
\end{tabular}

Sequences labelled "BH" stands for H. nehereus from Bangladesh used in the present study and "CH" stands for $H$. nehereus from China.

Interspecific variation of sequences: In this study the interspecific variations of partial regions of $16 \mathrm{~S}$ rRNA gene between $H$. nehereus and $H$. microchir (AP002919.1) from Bangladesh and China are shown in Table 4.

For interspecies polymorphic sites analysis of Bombay duck fish, the sequence of $H$. nehereus and $H$. microchir were aligned. Alignment of the sequence indicated single nucleotide polymorphism varies at 29 positions with $4.9 \%$ polymorphism and positions are shown in Table 4. Similar type of interspecies polymorphism showed in Barilius spp. (Singh et al. 2015) when $16 \mathrm{~S}$ rRNA gene was compared among Barilius bakeri, B. gatensis, B. vagra, B. bendelisis and $B$. tile.

Phylogenetic analysis: As Bombay duck is a lizardfish, a comparative study was performed among lizardfish from Harpadontidae and synodontidae family using the neighbor joining method, with bootstrap value 1000 where Labeo rohita was used as an out group. In the present study, Harpadon nehereus and H. microchir, belong to the family Harpadontidae, form a monophyletic clade with bootstrap value 96 (Fig. 4). Monophyly of these two species of Harpadon in the present study agreed with the result based on cytochrome c oxidase sub unit I (COI) gene (Nugroho et al. 2017). Furthermore, Saurida wanieso and S. umeyoshii along with $S$. undosquamis belong to the family Synodontidae form a monophyletic clade with bootstrap value 99 and similar result was also observed based on COI gene (Nugroho et al. 2017). 
Table 4. Polymorphic sites analysis of nucleotide sequence of $16 \mathrm{~S}$ rRNA gene between Harpadon nehereus and H. microchir (AP002919.1)

\begin{tabular}{lcll}
\hline Serial No. & Polymorphic sites & HM & HN \\
\hline 1 & 51 & C & T \\
2 & 52 & G & A \\
3 & 108 & T & C \\
4 & 116 & A & G \\
5 & 159 & A & C \\
6 & 180 & C & T \\
7 & 182 & T & C \\
8 & 199 & A & G \\
9 & 202 & A & T \\
10 & 203 & A & T \\
11 & 204 & C & T \\
12 & 254 & A & G \\
13 & 255 & G & A \\
14 & 262 & A & G \\
15 & 265 & C & G \\
16 & 266 & C & T \\
17 & 267 & A & G \\
18 & 269 & - & A \\
19 & 274 & G & A \\
20 & 294 & G & C \\
21 & 309 & C & T \\
22 & 358 & A & T \\
23 & 362 & A & C \\
24 & 368 & A & G \\
25 & 372 & C & T \\
26 & 379 & T & C \\
27 & 382 & C & T \\
28 & 411 & C & A \\
29 & 422 & & C \\
\hline & & &
\end{tabular}

Sequences labelled "HM" stands for H. microchir and "HN" stands for H. nehereus.

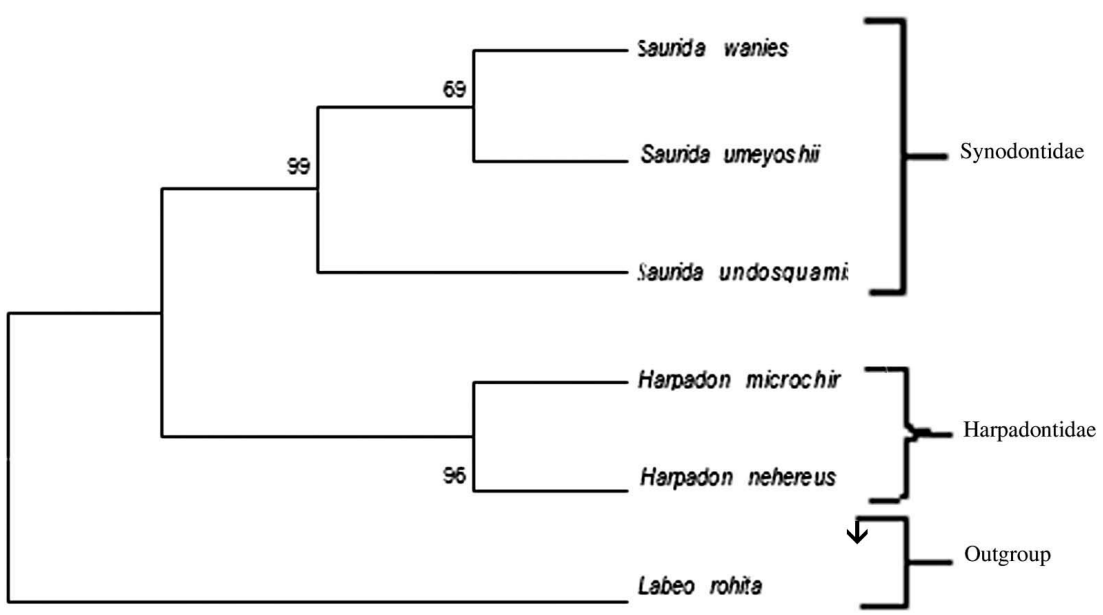

Fig. 4. Molecular phylogenic tree for lizardfish according to the neighbor joining method based on the partial nucleotide sequences for the 16S rRNA gene. 
Where Harpadon nehereus was used in the present study and $H$. microchir (AP002919.1), S. wanieso (NC 025940.1), S. undosquamis (NC 003162.1), S. umeyoshii (KM189365.1) were collected from GenBank database. Labeo rohita (KR185963.1) was used as out group.

Partial nucleotide sequence of 16S rRNA gene of Harpadon spp. of the present study was initially used to analyze the polymorphic loci and to construct a molecular phylogenetic tree. To confirm the present observation, further study is required based on nucleotide sequences of 12S rRNA, COI, cytochrome $b$, ND4 and ND1 genes.

\section{LITERATURE CITED}

BEJ, D., SAHOO, L., DAS, S.P., SWAIN, S., P. JAYASANKAR, P., DAS, P.C., ROUTRAY, P., SWAIN, S.K., JENA, J.K. and DAS, P. 2012. Complete mitochondrial genome of Labeo rohita. Mitochondrial DNA 23(6): 441-443.

BHUIYAN, M.R.U. 1992. Proximate biochemical analysis and spoilage pattern of six marine fishes of the Bay of Bengal. M.Sc. Thesis, Institute of Marine Science, University of Chittagong, Bangladesh. pp. 24-28.

BO, Z., XU, T., WANG, R., JIN, X. and SUN, Y. 2013. Complete mitochondrial genome of the Bombay duck Harpodon nehereus (Aulopiformes, Synodontidae). Mitochondrial DNA. 24(6): 660-662.

DEVEREUX, R and WILKINSON, S.S. 2004. Amplification of ribosomal RNA sequences. Molecular Microbial Ecology 301: 509-522.

DOYLE, J.J and DOYLE, J.L. 1990. Isolation of plant DNA from fresh tissue. Focus. 12: 13-15.

FAUCHER, L., GODE, C. and AMAUD, J.F. 2016. Development of nuclear microsatellite loci and mitochondrial single nucleotide polymorphisms for the natterjack toad, Bufo (Epidalea) calamita (Bufonidae), using next generation sequencing and competitive allele specific PCR (KASPar). Journal of Heredity 107: 660-665.

GOPAL, B. and CHAUHAN, M. 2006. Biodiversity and its conservation in the Sundarban mangrove ecosystem. Aquatic Sciences 68: 338-354.

HEDRICK, P.W. 2001. Conservation genetics: where are we now? Trends in Ecology and Evolution 16(11): 629-636.

NUGROHO, E.D., NAWIR, D., AMIN, M. and LESTARI, U. 2017. DNA barcoding of nomei fish (Synodontidae: Harpadon spp.) in Tarakan Island, Indonesia. AACL Bioflux. 10(6): 1466-1474.

PATWARDHAN, A., RAY, S. and ROY, A. 2004. Molecular Markers in Phylogenetic Studies - A review. Journal of Phylogenetics and Evolutionary Biology 2: 2-9.

RAHMAN, A.K.A. 1989. Freshwater Fishes of Bangladesh. Zoological Society of Bangladesh. Department of Zoology, University of Dhaka, pp. 364.

RAHMAN, A.K.A. 2005. Freshwater Fishes of Bangladesh, Second edition. Zoological Society of Bangladesh, University of Dhaka, Dhaka, Bangladesh, pp. 394.

SINGH, A.K., KUMAR, R., SINGH, M., MISHRA, A.K., CHAUHAN, U.K., BAISVAR, V.S., VERMA, R., NAGPURE, N.S and KUSHWAHA, B. 2015. Mitochondrial 16S rRNA gene-based evolutionary divergence and molecular phylogeny of Barilius spp. Mitochondrial DNA 26(1): 41-47.

SARKER, M.N., HUMAYUN, M., RAHMAN, A. and UDDIN, M.S. 2017. Population dynamics of bombay duck harpodon nehereus (Hamilton, 1822) of the Bay of Bengal along Bangladesh coast. Bangladesh Journal of Zoology 45(2): 108-109. 
SUlTANA. A., BEGUM, R.A., JAHAN, H., ALAM, M.S. and SHAHJAHAN, R.M. 2015. Nucleotide sequence of 16S rRNA gene of Clarias gariepinus and its molecular phylogeny with other catfishes. International Journal of Research in Fisheries and Aquaculture. 5(1): 33-40.

WEISBURG, W.G., BARNS, S.M., PELLETIER, D.A. and LANE, D.J. 1991. 16S ribosomal DNA amplification for phylogenetic study. Journal of Bacteriology 173: 697-703.

WHITEHEAD, P.J.P. 1984. Harpadontidae. In: Fisheries, W. and G. Bianchi (eds.). FAO Species identification sheets for fishery purposes. Western Indian Ocean fishing area 51. Vol. 2 FAO, Rome.

WOESE, C.R. and FOX, G.E. 1977. Phylogenetic structure of the prokaryotic domain: The primary kingdoms. Proceedings of the National Academy of Sciences of the United States of America 74(11): 5088-5090.

VENCES, M., THOMAS, M., VAN DER MEIJDEN, A., CHIARI, Y. and VIEITES, D.R. 2005. Comparative performance of the 16S rRNA gene in DNA barcoding of amphibians. Frontiers in Zoology 2: 5-6.

YANG, L., HIRT, M.V., SADO, T., ARUNACHALAM, M., MANICKAM, R., TANG, K.L., SIMONS, A.M., WU, H., MAYDEN, R.L. and MIYA, M. 2012. Phylogenetic placements of the barbin genera discharodontus in the subfamily cyprinidae and their relationships with other barbins. Zootaxa 3538: $26-40$.

YANG, L., TAN, Z., WANG, D., XUE, L., GUAN, M., HUANG, T. and LI, R. 2014. Species identification through mitochondrial rRNA genetic analysis. Science Reports 4: 4089.

ZAFAR, M., HOSSAIN, Z. and MEHDI, A. 1993. Calcium content in some commercially important fishes in the Bay of Bengal, Bangladesh. Chittagong Univ. Stud. Part. II. Sci. 17: 63-66. 